\title{
What we talk about when we talk about 'systems thinking'
}

Article

Accepted Version

Lane, D. C. (2016) What we talk about when we talk about 'systems thinking'. Journal of the Operational Research

Society, 67 (3). pp. 527-528. ISSN 0160-5682 doi: https://doi.org/10.1057/jors.2015.10 Available at https://centaur.reading.ac.uk/65582/

It is advisable to refer to the publisher's version if you intend to cite from the work. See Guidance on citing.

Published version at: http://www.palgrave-journals.com/jors/journal/v67/n3/pdf/jors201510a.pdf

To link to this article DOI: http://dx.doi.org/10.1057/jors.2015.10

Publisher: Palgrave Macmillan

All outputs in CentAUR are protected by Intellectual Property Rights law, including copyright law. Copyright and IPR is retained by the creators or other copyright holders. Terms and conditions for use of this material are defined in the End User Agreement.

\section{www.reading.ac.uk/centaur}

\section{CentAUR}

Central Archive at the University of Reading

Reading's research outputs online 
This document is the pre-peer reviewed version of the following article:

Lane DC. 2016. What We Talk About When We Talk About 'Systems Thinking'. Journal of the Operational Research Society 67(3): 527-528.

which has been published in final form at:

http://www.palgrave-journals.com/jors/journal/v67/n3/pdf/jors201510a.pdf

Note that the published version may have some differences from the version here. In all cases, the published version takes precedence.

If you wish to cite the ideas in this paper then please cite the version published in Journal of the Operational Research Society, NOT this version.

Please contact the Corresponding Author if you have any queries.

\section{Viewpoint: What We Talk About When We Talk About 'Systems Thinking'}

I enjoyed the recent application of causal loop diagraming by Sharif et al. (2014). The paper contributes to the domain of sustainable operations management by employing mapping ideas derived from System Dynamics (Forrester, 1961, 1968b). In so doing, it seeks to contrast 'Systems Thinking' and 'Soft OR'. Somewhat to my surprise, it does so by offering agreement with definitions said to have been given in a conference paper of mine (Lane, 1993). Unfortunately, I do not feel that the definitions attributed to me are to be found in the 1993 paper - nor in its subsequent journal manifestation (Lane, 1994). More importantly, the definitions do not, I would suggest, provide particularly helpful explanatory value. Indeed, I am concerned that they might lead to some possible confusion regarding the nature and aspirations of System Dynamics Modelling. I would therefore like here to offer a clarification.

Discussions in this area have appeared previously on the pages of JORS (Checkland, 1994, Lane, 1995, Wolstenholme, 1994). The discussion then was triggered by the use of the term 'Systems Thinking' by Peter Senge to describe how the qualitative parts of System Dynamics - causal loop 
diagramming and system archetypes - might be used to support organisational learning (Senge, 1990). The issue was whether the distinctive contribution that System Dynamics Modelling can offer was being watered down by association with the term 'Systems Thinking' (Forrester, 1994). Aspects of that debate hold relevance in so far as they relate both to the place that System Dynamics Modelling holds in the field of Systems Science and to its contribution to Operational Research generally. These points therefore merit some clarification.

In order to progress I would like to offer three brisk and to-the-point definitions of 'Systems Thinking'.

Definition 1: Systems Thinking means Systems Science. In this definition the term is used to refer to the very wide range of approaches which adopt an holistic approach to analysis. Examples of this usage are many, varied and spread across a long period of time; see Emery (1969), Checkland (1978) and Jackson (2009).

Definition 2: Systems Thinking means 'Soft Systems Methodology'. This definition arguably derives from the title of the book that gave the world the first detailed description of the aspirations, assumptions and operation of Peter Checkland's SSM (Checkland, 1981).

Definition 3: Systems Thinking means the qualitative parts of System Dynamics Modelling. Whilst Senge's (1990) usage attracted the most attention, the idea that elements of the System Dynamics approach might be possible without the rigour of computer simulation had appeared earlier (Roberts, 1978) and continue happily today (Richmond, et al., 2010).

All three definitions can make sense and be useful in conveying understanding - as long as one is clear about which is being used. It is in relation to Definition 3 that I would like to offer a clarification before then commenting briefly on the contrast between 'Systems Thinking' and 'Soft $O R^{\prime}$.

One must start with 'System Dynamics'. This is a method of inquiry that concerns itself with behaviour over time and the causal mechanisms that can usefully be seen as generating that behaviour. System Dynamics is a systems approach with a specific interest in feedback effects (Richardson, 1991) - but not just in those effects. Rather, those mechanisms are conceptualised 
around the ideas of causal links, feedback loops, stocks and flows and guiding policy structures, with these all viewed as sitting within a causally closed boundary (Forrester, 1968a). These mechanisms constitute a 'causal hypothesis'; the suggestion is that the time evolutionary behaviour can be seen as resulting from their operation. Framing those mechanisms as a formulated and parameterised simulation model allows for the rigorous testing of that hypothesis. In this way it is possible first to explain counter-intuitive behaviour in causal terms but then to use this explanation as a platform from which to suggest interventions which generate different behaviour. The use of such approaches within a group can create understanding and changed mental models which lead to more effective policies and actions from both management and staff alike (Forrester, 1965, 1971).

In this context, 'Systems Thinking' uses qualitative maps rather than simulation models. The roles played by such maps are varied and have - aptly - changed over time (Lane, 2008). Whilst there are comparisons with other systems and OR approaches that have a role for mapping (Lane and Husemann, 2009), this 'Systems Thinking' retains a specific interest in behaviour over time. The notes of caution are, first, that mapping has representational limitations (Richardson, 1986, 1997), and, second, that the hypothesis testing is less rigorous: whilst a simulation model deduces behaviour, a map can only be used to infer behaviour. Those caveats aside, 'Systems Thinking' is a powerful tool for helping individuals and groups understand long chains of consequence, unanticipated consequences, feedback effects and the source of observed behaviour. It is primarily this third definition of 'Systems Thinking' that is implicitly used in the paper in question (Sharif, et al., 2014).

The contrast between this and 'Soft $\mathrm{OR}^{\prime}$ ' is more problematic. After years of effort Jonathan Rosenhead convinced me that 'Soft $O R^{\prime}$ was an uneasy term and that 'Problem Structuring Methods' was superior. As 'PSMs', his usage seems to have won the day and, whilst the understanding of the area has - naturally - evolved, for a sense of what distinctive features PSMs bring to the spectrum of $O R$ it is hard to find a better place to enter the territory than the introduction to his 1989 collection (Rosenhead, 1989). The difficulty is that there is not one definition of PSMs, more that they are a set of approaches that have all departed from a notion of 'Hard OR' (c.f. Pidd, 1996, Rosenhead, 1996). If all PSMs share common features - a contestable point - then these perhaps relate to a broader understanding of what a useful 'model' might be (not necessarily mathematical) and a consistent interest in (and therefore need to do research on) the 
participative process employed when using and evaluating such methods (e.g. Andersen, et al., 2007, Eden and Ackermann, 2013).

To return to the clarifying purpose of this Viewpoint: within Definition 3 'Systems Thinking' is a specific mapping approach derived from System Dynamics Modelling, whilst 'PSMs' is a broad range of participative modelling/mapping approaches. I hope that this might help avoid the confusion that I otherwise feared - though none of this detracts from the contribution to sustainable operations management in the original paper.

David C Lane

Henley Business School

Submitted August 2014

\section{References}

Andersen DF, Vennix JAM, Richardson GP and Rouwette EAJA (2007) Group model building: problem structuring, policy simulation and decision support. Journal of the Operational Research Society 58(5): 691-694.

Checkland PB (1978) The origins and nature of 'hard' systems thinking. Journal of Applied Systems Analysis 5(2): 99-110.

Checkland PB (1981) Systems Thinking, Systems Practice. Wiley: Chichester.

Checkland PM (1994) Playing language games. Journal of the Operational Research Society 45(7): 851-852.

Eden C and Ackermann F (2013) Problem structuring: on the nature of, and reaching agreement about, goals. EURO Journal on Decision Processes 1(1): 7-28.

Emery FE (1969) Systems Thinking: Selected readings. Penguin: Harmondsworth.

Forrester JW (1961) Industrial Dynamics. MIT Press: Cambridge, MA.

Forrester JW (1965) A New Corporate Design. Industrial Management Review (now the Sloan Management Review) 7(1): 5-17.

Forrester JW (1968a) Market growth as influenced by capital investment. Industrial Management Review (now the Sloan Management Review) 9(2): 83-105.

Forrester JW (1968b) Principles of Systems. MIT Press: Cambridge, MA.

Forrester JW (1971) "The" model versus a modelling "process" (republished 1985). Dept. memo D1621-1, system dynamics group, MIT, republished in System Dynamics Review 1(1): 133-134.

Forrester JW (1994) System Dynamics, Systems Thinking, And Soft OR. System Dynamics Review 10(2-3): 245-256.

Jackson MC (2009) Fifty Years of Systems Thinking for Management. Journal of the Operational Research Society 60(S1): S24-S32.

Lane DC (1993) With A Little Help From Our Friends: How third generation system dynamics and the issue structuring techniques of 'soft' OR can learn from each other. In eds. Zepeda, E and 
Machuca, JAD System Dynamics 1993: The role of strategic modelling in international competitiveness. System Dynamics Society: Albany pp 235-244.

Lane DC (1994) With A Little Help From Our Friends: How system dynamics and 'soft' OR can learn from each other. System Dynamics Review 10(2-3): 101-134.

Lane DC (1995) Trying to think systematically about 'systems thinking'. Journal of the Operational Research Society 46(9): 1158-1162.

Lane DC (2008) The Emergence and Use of Diagramming in System Dynamics: A critical account. Systems Research and Behavioral Science 25(1): 3-23.

Lane DC and Husemann E (2009) What Does The Arrow Mean? Observations on system dynamics mapping and the potential for experimentation with other methods. In eds. Strohhecker, J and Größler, A Strategisches und operatives Produktionsmanagement - Empirie und Simulation. Gabler: Wiesbaden pp 327-350.

Pidd M (1996) Tools For Thinking: Modelling in management science. John Wiley: Chichester.

Richardson GP (1986) Problems with casual-loop diagrams (originally published in 1976). System Dynamics Review 2(2): 158-170.

Richardson GP (1991) Feedback Thought in Social Science and Systems Theory. Univ. Pennsylvania: Philadelphia.

Richardson GP (1997) Problems in casual-loop diagrams revisited. System Dynamics Review 13(3): 247-252.

Richmond J, Stuntz L, Richmond K and Egner J (eds.). (2010) Tracing Connections: Voices of systems thinkers. Lebanon NH \& Acton MA: isee systems inc. \& The Creative Learning Exchange.

Roberts N (1978) Teaching dynamic feedback systems thinking: an elementary view. Management Science 24(8): 836-843.

Rosenhead J (1989) Introduction: old and new paradigms of analysis. In ed. Rosenhead, J Rational Analysis for a Problematic World: problem structuring methods for complexity, uncertainty and conflict. Wiley: Chichester pp 1-20.

Rosenhead J (1996) What's The Problem? An introduction to problem structuring methods. Interfaces 26(6): 1-24.

Senge PM (1990) The Fifth Discipline: The art and practice of the learning organization. Doubleday/Currency: New York.

Sharif AM, Alshawi S, Kamal MM, Eldabi T and Mazhar A (2014) Exploring the role of supplier relationship management for sustainable operations: an OR perspective. Journal of the Operational Research Society 65(6): 963-978.

Wolstenholme EF (1994) Response to Professor Checkland's Comments. Journal of the Operational Research Society 45(7): 853-854. 